\title{
IRREGULAR ATTENDANCE OF UNIVERSITY STUDENTS AT CLASS AND ITS RELATION TO THEIR ACADEMIC ACHIEVEMENT
}

\author{
Shanti Prasad Khanal
}

\begin{abstract}
The paper intends to examine the irregular attendance of students in their class and its relation to their academic achievement in five central campuses of Mid- Western University. This study followed descriptive study based on quantitative and qualitative data. Quantitative data were obtained from 172 students selected by non-proportional stratified sampling. Qualitative data were obtained from the campus chiefs, heads of instruction committees and teachers of the central campuses selected purposively. A mixed questionnaire was employed for quantitative data and open ended questionnaire was used to collect qualitative data. The study showed that near about half portion of respondents responded that they were sometimes irregular in their class. Few students $(4.45 \%)$ who were never irregular belonged to the category of having knowledge of irregular attendance. Higher portion (29.57\%) of the male students were always irregular than the female students. The high portion of Master's level students were always irregular than the Bachelor's level students. Chhetri students were always irregular than other castes. The higher percentage (23.07\%) of 20 to 25 years' age group students were always irregular than other age groups. The percentage of irregular students seemed higher in central campus of Humanities and Social Science, Education and Management. Majority of the participants pointed out that the University related factors are main reasons for their irregular attendance. The study showed that there is a positive significant relationship between class attendance of students and their academic achievement.
\end{abstract}

Keywords: Irregular Attendance, Frequency, Reasons, Academic Achievement

1 Mr. Khanal is a Lecturer, Surkhet Campus (Education), Surkhet, T.U. 


\section{INTRODUCTION AND OBJECTIVE}

Regular attendance is one of the primary reasons for students' success in education. Attendance at class is not merely being bodily present but including actual participation in the work and activities of the class (Fagbenle \& Elegbeleye 2014). It is defined as an absence for an entire college day, a major portion of the class day, or the major portion of any class, study hall for which the student is scheduled (Belvin 2009). It jeopardizes chances of achieving their educational goals. Its consequences often lead to increased costs (Iheanyi \& Ikechi 2012). It is the act of deliberately missing one or more classes. Irregularity is any intended, and illegal absence from compulsory class. It also refers to students who attend campus but do not go to the classes. It is an act of staying off class which is one of the several types of disruptive behaviors (Okwakpam \& Okwakpam 2012).

Academic performance is the outcome of the education the degree to which a student, teacher and institute have achieved educational goal. It is commonly measured by examination or continuous assessment. Regular class attendance precedes learning achievement. In order to be benefited for students from the educational program they must have good attendance. Irregular students have less opportunities to study. Thus, their academic potential is hindered. Therefore, regular class attendance is a high priority in semester systems.

Mid-Western University (MU) was established in 2010. It offers diverse academic programs independently. There are five faculties (Humanities and Social Sciences, Management, Education, Science and Technology and Engineering) under which there are five constituent campuses (The central Campus of Humanities and Social Sciences, Management, Education, Science and Technology and Engineering) have been conducting in graduate and undergraduate level (MU 2016). MU has adopted semester system based curriculum. Undergraduate level, eight semesters with four years and graduate level have four semesters within two years courses are extended. In semester system, almost regular attendance is necessary. The students who are not regular attended in the class, they are not allowed in the written exams. There must be $80 \%$ attendance of the students in Mid-Western University. Instead of this, the students are attended irregularly in all faculties. So, irregular attendance of the students 
is one of the challenging and emerging problems in whole faculties of the university.

The irregularity of the students in University has been a recurrent issue. In most cases, many of these students come late in the morning. They leave class before closing hours for other unofficial actions and in some cases too (DeKallb 1999). The problem of students' irregular attendance in their class is also spreading around the globe and different levels of education. If this problem is not addressed, it may have devastating consequences on the excellence of graduates from the Universities.

Cause of irregularity of University students around the globe is categorized and linked student with factors, university factors, economic and family factors (Fayombo et al. 2012). Higher education institutions sometimes follow different attendance policies and practices: some make it compulsory and many institutions believe in its positive effect in academic performance (Guleker and Keci, 2014). Oghuvbu (2010) found a positive correlation between attendance and academic performance. The findings by Andrietti et al. (2008) are supported by (Chishima 2016) who hypothesized that regular present of students in class positively affects the learning outcomes (Chishima 2016).

As a teacher, teaching at the University where semester system is running, I have observed the irregularity of students in the class. So, I am very interested and concerned in this issue. From the above reviewed literatures, and my experiences, it is marked that absenteeism from class is a main issue among the University students. However, the reasons of poor attendance are not studied properly. Students are absent in classes for a variety of reasons. So, irregularity of the students in their class is taken as a problem that either directly or indirectly affects all educational stakeholders. Irregular attendance is not only moral to university; it is a great educational issue to be addressed in current time. It is an educational and social problem. Students' non-attendance to class is a problem that spreads much in the University. It affects the students, the family and the society on very high levels. So, it should be taken as the most powerful predictor of misbehavior and disruptiveness among students. It determines the student's achievement and their potentiality. This leads to increase poor academic performance that will cause students' drop out from their study. Upon this 
context, the paper aims to examine the situation of irregular attendance of students at class and its relation to their academic achievement in MidWestern University. Similarly, I have formulated a hypothesis that there is significance relationship between attendance of the students of the class and their academic performance.

\section{THEORETICAL FRAMEWORK}

This study followed the Engestrom's Activity Theory which assumes that human action takes place within specific social and historical contexts that are inseparable from the action. Futhermore, Engeström, 1993 (Scheckle 2014) holds that an activity system integrates the subject, object and the instruments into a unified whole (Scheckle 2014). In Activity Theory, the relationship between subject and object forms the core of an activity (Hasan \& Kazlauskas 2014). Scheckle (2014) presents the key argument of this model that are presented below.

The University community of lecturers, tutors, supplemental instruction leaders, language and writing consultants, student, counselors and librarians depicted as facilitating students' learning. The community is depicted as providing support and encouragement to its children who are studying. The tools and rules defined by the University and aligned with institutional standards. tools include texts, lectures, tutorials, lecturers, peers, finance (for food, medical needs, stationery, transport) and programs which all mediate the learning experience. The community would be the stakeholders such as the University community, that of the home and that of the city, they are not the primary subjects but they share the object of the activity (p. 611-612).

\section{MATERIALS AND METHOD}

This study followed descriptive cross-sectional study designed based on quantitative and qualitative data which was carried out in Mid -Western University, Surkhet. All $(2,299)$ students who were studying in all five central campuses of Mid-Western University and their campus chiefs, head of the instruction committees and the teachers were the study population for the study. Out of total, $172(7.48 \%)$ students from central 
campuses of MU (43 students from Central campus of Education, 46 from Central Campus of Humanities and Social sciences, 50 from Central Campus of Management, 19 from Central Campus of Science and Technology, and 14 students from Central Campus of Engineering) were selected as participants for quantitative data using non proportional stratified sampling. On the basis of central campuses, five strata were made. The students in each central campus were further listed using a list provided by the central office of the University. Random sampling (lottery) was used to pick the respondents in each stratum.

The study also used qualitative data obtained from 15 participants, the campus chiefs (5), heads of instruction committees (5) and teachers of the central campuses (5) were selected purposively. A mixed type of questionnaire was employed for quantitative data and open ended questionnaire was used to collect qualitative data. The collected data were checked, ordered, edited and coded. Then, they were analyzed manually. Chi-square test was used to find out the relationship between attendance of students and their academic achievement. For the computation of chisquare test, the Karl Pearson's method was used.

\section{RESULT AND DISCUSSION}

This section addresses three subheadings like situation of irregular attendance, reasons to irregular attendance of the students and relationship between attendance of the students and their academic achievement.

\section{Situation of irregular attendance}

Situation of irregular attendance of the students is examined on the basis of its frequency, students' knowledge and students' profile including sex, age, cast, level and faculties.

\section{Frequency of students' irregular attendance}

The students' classroom attendance rate differs. The frequency of students' attendance is not similar. The frequency of attendance has identified in the study which is presented in following Table 1. 
120 IRREGULAR ATTENDANCE OF UNIVERSITY STUDENTS ...

Table 1: Frequency of students' irregularity

\begin{tabular}{llcc}
\hline Description & & Number & Percent \\
\hline \multirow{3}{*}{ Frequency } & Always & 37 & 21.51 \\
& Sometimes & 79 & 45.93 \\
& Rare & 49 & 28.49 \\
& Never & 7 & 4.06 \\
\hline & Total & 172 & 100.00 \\
\hline
\end{tabular}

Source: Field Study (2017)

Table 1 shows that about half of 79 students (45.93\%)responded that they were irregular in their class sometimes. Likewise, 49 (28.49\%) said that they were always irregular in their class, 21.5 percent said that they were rarely irregular and only 7 (4.06\%) students were never irregular in the classes.

On pooling up the data of Mid-Western University, the students were more irregular sometime and always. This data indicates in overall that students' irregularity in the University is high. Semester system focuses on the regular attendance of the students. So, according to this finding, it may raise a question about the implementation of semester system in the University.

\section{Students' personal characteristics and their irregular attendance}

Students' personal characteristics such as sex, age, caste, level and faculty are determinants of students' irregular attendance in their classes. Table 2 shows the situation of irregular attendance of the students' in the class on the basis of students above-mentioned personal characteristics.

According to Table 3, higher portion (29.57\%) of the male students were always irregular than the female students (15.84\%). But nearly half $(47.52 \%)$ of the female students were sometimes irregular than the male students $(43.66 \%)$. The percentage of female students in rare and never irregular was also higher than the percentage of male students where female were 31.68 percent and 4.95 percent and male were 23.94 percent and 2.81 percent respectively. 
On the basis of age, the high percentage of (23.07\%) 20 to 25 years' students were always irregular than other age group students. Similarly, the higher percentage of 30 years above $(53.33 \%)$ students' irregularity was sometime. Below 20 years, 32\% were rarely irregular. This table 2 shows that the percentage of students below 20 years $(8 \%)$ was never irregular which is higher than the other age groups.

Table 2: Situation of irregular attendance of the students' on the basis of students' personal characteristics

\begin{tabular}{|c|c|c|c|c|c|c|c|c|c|c|c|}
\hline \multirow{2}{*}{\multicolumn{2}{|c|}{$\begin{array}{c}\text { Students' personal } \\
\text { characteristics }\end{array}$}} & \multicolumn{2}{|c|}{ Always } & \multicolumn{2}{|c|}{ Sometime } & \multicolumn{2}{|c|}{ Rare } & \multicolumn{2}{|c|}{ Never } & \multicolumn{2}{|c|}{ Total } \\
\hline & & No* & P\#. & No* & P.\# & No* & P.\# & No* & P.\# & No* & P.\# \\
\hline \multirow[t]{2}{*}{ Sex } & Male & 21 & 29.57 & 31 & 43.66 & 17 & 23.94 & 2 & 2.81 & 71 & 41.27 \\
\hline & Female & 16 & 15.84 & 48 & 47.52 & 32 & 31.68 & 5 & 4.95 & 101 & 58.72 \\
\hline \multirow[t]{4}{*}{ Age (years) } & Below 20 & 5 & 20 & 10 & 40 & 8 & 32 & 2 & 8 & 25 & 14.53 \\
\hline & $20-25$ & 21 & 23.07 & 42 & 46.15 & 25 & 27.47 & 3 & 3.29 & 91 & 52.90 \\
\hline & $26-30$ & 9 & 21.95 & 19 & 46.34 & 12 & 29.26 & 1 & 2.43 & 41 & 23.83 \\
\hline & 30 above & 2 & 13.33 & 8 & 53.33 & 4 & 26.66 & 1 & 6.66 & 15 & 8.72 \\
\hline \multirow[t]{4}{*}{ Caste } & Chhetri & 16 & 23.88 & 30 & 44.77 & 19 & 28.35 & 2 & 2.98 & 67 & 38.95 \\
\hline & Brahmins & 8 & 16.66 & 21 & 43.75 & 15 & 31.25 & 4 & 8.33 & 48 & 27.90 \\
\hline & Janajati & 8 & 23.52 & 16 & 47.05 & 9 & 26.47 & 1 & 2.94 & 34 & 19.76 \\
\hline & Dalit & 5 & 21.73 & 12 & 52.17 & 6 & 26.08 & - & - & 23 & 13.37 \\
\hline \multirow[t]{2}{*}{ Level } & Bachelor's & 22 & 17.05 & 61 & 47.28 & 40 & 31.00 & 5 & 3.87 & 129 & 75 \\
\hline & Master's & 15 & 34.88 & 17 & 39.53 & 9 & 20.93 & 2 & 4.65 & 43 & 25 \\
\hline \multirow[t]{5}{*}{ Faculty } & Education & 10 & 23.25 & 24 & 55.81 & 9 & 20.93 & - & & 43 & 25 \\
\hline & Humanities & 12 & 26.08 & 26 & 56.52 & 8 & 17.39 & - & & 46 & 26.74 \\
\hline & Management & 13 & 26 & 28 & 56 & 9 & 18 & - & & 50 & 29.06 \\
\hline & $\begin{array}{l}\text { Science and } \\
\text { technology }\end{array}$ & 2 & 10.52 & 1 & 5.26 & 13 & 68.42 & 3 & 15.78 & 19 & 11.04 \\
\hline & Engineering & - & - & - & - & 10 & 71.42 & 4 & 28.57 & 14 & 8.13 \\
\hline
\end{tabular}

Source: Field Study (2017)

No*, Number P*: Percent

On the basis of cast, the Chhetri students were always irregular more than other castes. Half of the Dalit students $(52 \%)$ were sometimes irregular than others. The high percentage (31.25\%) Brahmins were rare irregular in the class.

On the basis of level, always irregularity of Master's level students was higher than the Bachelor's level. But irregularity sometimes of Bachelor's level students' percentage was higher in than the master's level. 
Students of Bachelor's level (31\%) were rarely irregular than the Master level $(20.9 \%)$. The high percentage of never irregular students was Master's level (4.65\%) than the Bachelor's level (3.87\%).

On the basis of faculty, the percentage of always irregular students is higher in Faculty of Humanities and Social Science where 26.08 percent students were always irregular. Similarly, sometimes irregular students' percentage is higher in humanities rather than other faculties'. Most of the students $(71.42 \%)$ of engineering faculty were rarely irregular in comparison to other faculties. At last, the higher percentage students of engineering (28.57\%) were never irregular in the class.

The finding from Table 2 shows that there is difference in the frequency of irregular attendance between the students according to their sex, age, cast level and faculty. The study examined that overall situation of the University students' attendance situation is low. The attendance situation of the girls was a little higher than that of boys. There was not much difference between attendance situations of students of different caste butcher was a little less than that of students of other castes. The attendance situation of students at Masters Level was low than the Bachelor's level student. Students of engineering faculty were rarely irregular in comparison to other faculties. In semester system, almost regular attendance is necessary. The students who are not regular attended they are not allowed in the examination. There must be $80 \%$ attendance of the students in the classes. Instead of this, the students are attended irregularly in all faculties. So, irregular attendance of the students is one of the challenging and emerging problems in whole faculties of the University.

The magnitude of irregular attendance at classes does not only affect the students' academic aspect but also impacts on teachers' ability to articulate the curriculum requirements, to plan and present instructional activities in an organized and meaningful way.

\section{Reasons to irregular attendance of the students}

It is found that there are several factors leads to irregular attendance of students in their classes of Mid-Western University. The reasons behind student's irregular attendance are mainly categorized into four major 
clusters. The analysis of these reasons using all the various sources of information collected during the study is presented in the Figure 1.

Figure 1 shows the causes of irregular attendance of students. Study participants were asked to identify what were the reasons for the student's irregular attendance of their class. Majority $(58.18 \%)$ of respondents pointed out the university/ faculty/campus related factors as main reasons. Likewise, about half (49.09\%) percent students responded that students themselves related factors are the reasons of student's irregular attendance. Similarly, Figure 1 showed that 32.12 percent indicated they missed class due to home and few $(11.51 \%)$ responded community related factors irregularity. This data from Figure 1 also reveals that the university related reasons to students' irregular attendance is multi-factorials. Majority said the reasons of students missing class due to university related factors and near about half (49.09\%) were due to students themselves related factors.

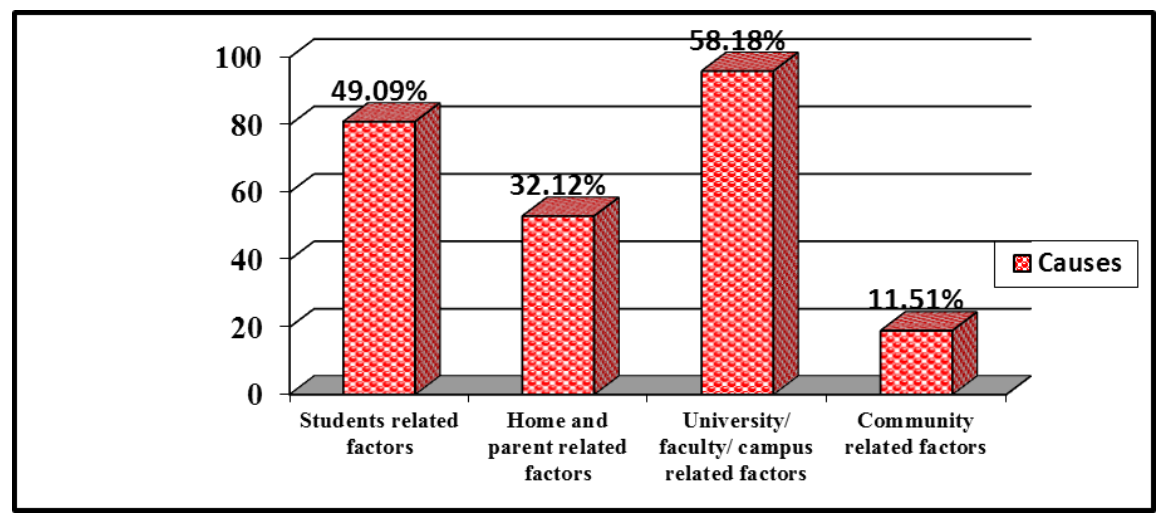

Figure 1: Reasons to irregular attendance of the students of the university

All participants of Open Ended Questionnaire (OEQ) (campus chiefs, heads of instruction committee and teachers) reported, university related factors and students themselves related factors as the main reasons of their irregular attendance. All participants of OEQ accepted that lack of sufficient number of classrooms; appropriate library, university cafeteria, and well managed toilet are main university related reasons for the irregular attendance. Few study participants of OEQ reported, wanting to miss particular subject was common. A small number of participants suggested, physical and psychological problems, learning difficulties, behavioral 


\section{IRREGULAR ATTENDANCE OF UNIVERSITY STUDENTS ...}

problems, and low self-esteem of the students as the reasons of irregular attendance. Some teachers reported that there is no strong administrative mechanism and evaluation system. Some participants of faculty of education and humanities argued, some of the teachers do not maintain the proper class attendance. Few heads of instruction committee and teachers noted that the campus also admits those students who told I cannot be regular in the daily class. A campus chief (out of 5) told, that irregular students are admitted due to the problem of proper number of students.

Most participants of OEQ argued that the students are lazy, and ignore their study. Some students drop out a class after gaining a job. They give priority to their job than their education. Some of them are employed at boarding schools and other organizations. So, they become irregular in their class. A small number of participants of OEQ suggested, physical and psychological problems, learning difficulties, behavioral problems, and low self-esteem as the reasons of irregular attendance. Few claimed, they become irregular at class simply to be with friends. Some students were influenced to stay away by friends and classmates or to demonstrate their toughness to their peers. About half participants indicated, they have a concept of being passed without attending the classes. Students have low desire to be a competent and to choose interested subject. Minority (3 out of 15) noted they do not want to get out of bed at the morning. Some campus chiefs, heads of the instruction committee and teachers stated that parents involve them in agricultural activities such as cultivation of harvest and their newly harvested corn.

This study concluded that university related factors are a main reason to students' irregular attendance of their classes. (MU 2016) also stated that Mid-Western University lacks motivating program to empower faculty members. Regularly faculty programs are not developed. HRM mobilization is less effective. It reflects that the important should be given in physical facilities and mental environment as well as teaching learning of university to make the students regular. The main reasons that the students do not like attending regularly to class specified by them was university lacks physical facilities and mental environment. This means students can't learn as much as they can when the teaching learning could not meet their wants and wishes. 


\section{Relationship between attendance of students' and their academic achievement}

Irregular attendance impacts on pupil attainment. Interconnected effects of irregular attendance on students who miss class are academic underachievement difficulty. It breaks the continuity of learning etc. Some previous researches concluded that there is positive relationship between students' attendance and their academic performance. Table 4 shows the relationship between attendance and academic achievement of the University Students.

Table 3: Relationship between attendance and academic achievement of the University Students

\begin{tabular}{lccccc}
\hline \multicolumn{1}{c}{ Variable } & $\chi 2$ cal & Df & \multicolumn{2}{c}{$\chi 2$ tab } & Sig. \\
\hline Relationship between & 63 & 12.50 & 21.03 & 26.33 & $\mathrm{~S}^{*}$ \\
attendance and academic & & & $(0.05)$ & $(0.01)$ & \\
performance & & & & & \\
\hline
\end{tabular}

Source: Field Study (2017)

Table 3 shows that the Tabulated value 63 is greater than calculated value for 0.05 and 0.01 level of significance of df 12 . So, Null Hypothesis is rejected. The results showed that the calculated Chi-square value $(\chi 2 \mathrm{cal}$ $=63)$ is quite higher than the tabulated value $(\chi 2 \mathrm{tab}=21.03(0.05)$ and $26.33(0.01))$, hence the result is significant. This, therefore, supports the alternative hypothesis that a significant relationship exists between class attendance and academic achievement of the university/ higher level students. It is proved that here is a positive relationship between class attendance of students and their academic achievement. It is also revealed that academic achievement is influenced by students' attendance of higher level in the study area.

Studies have also showed that higher attendance is related to higher achievement for students of all backgrounds. A study by the U.S. Department of Education conducted in 2005 concluded that students who attend school regularly score higher on achievement tests than their students who are frequently absent (Bradly 2015). Duflo and Hanna's (2006) found fundamental relationship between teacher absenteeism and student outcomes. 


\section{CONCLUSION}

The study concluded that there is difference in the situation of irregular attendance of the students according to their age, caste, faculty, level and sex. The attendance situation of the girls was a little higher than that of the boys. There was not much difference between attendances of students of different castes. Master's level students' irregularity is higher than the Bachelor's level students. Girls from 20 to 25 years were always irregular than other age groups. Students of Engineering faculty were rarely irregular in comparison to other faculties. Behind the students' irregularity, there is not only one reason but many and multi-factorials. Engestrom's Activity theory also highlights that University, lecturers, home, peer, community, rule, tools etc are stakeholders to act of regular attendance. The study revealed that the university students, parents and community related factors are the four most significant reasons of irregular attendance among the university students. The study concluded that there is a significance relationship between class attendance of students and their academic performance. So, these four key reasons need to work in an integrated way in solving the problems of irregular attendance of students in the universities.

\section{REFERENCES}

Bradley, R.R. (2015). A comprehensive approach to improving student attendance. https://fisherpub.sjfc.edu/cgi/viewcontent.cgi?article= $1226 \&$ context=education_etd

Belvin, S.M. (2009). A study of student perceptions regarding attendance in a rural east Tennessee high school, $\mathrm{PhD}$ Thesis, East Tennessee State University.http://dc.etsu.edu/etd/1845, (Accessed:10/03/2073 B.S.).

Bond, G. (2004). Tackling student absenteeism: Research findings and recommendations for school and local communities. http://www. hwllen.com

DeKalb, J. (1999). Student truancy, ERIC Digest. http://eric.uoregon.edu/ publications/digests/digest125.html 
Duflo, O.E. \& Hanna, R. (2006). Monitoring works: Getting teachers to come to school. C.E.P.R. Discussion Paper.

Essays, UK. (2018). Regular attendance in all classes education essay. https://www.ukessays.com/essays/education/regular-attendancein-all-classes-education-essay.php?vref=1

Fagbenle, A.O. \& Elegbeleye, A.O. (2014). Attendance dilemma and its effects on the academic performance of secondary schools' students in Osun State, Nigeria, International Journal of Humanities Social Sciences and Education (IJHSSE) 1(4). www.arcjournals.org

Fayombo, G.A., Ogunkola, B.J. \& Olaleye, Y. I. (2012). Cross institutional study of the causes of absenteeism among university students in Barbados and Nigeria. Australian Journal of Educational and Developmental Psychology 2(1).

Guleker, R. \& Keci, J. (2014). The effect of attendance on academic performance. Mediterranean Journal of Social Sciences 5(23). https://pdfs.semanticscholar.org/b4d4/7a6ce23bac12418cccc3d6c a75c0273bbc70.pdf

Hasan, H \& Kazlauskas, A. (2014). Activity Theory: Who is doing what, why and how, www.dfs.semanticscholar.org/2027/4e59582e2288a ba22c137831c79f71e84cf0.pdf

Iheanyi, N.O. \& Ikechi, O.O. (2012). Causes and levels of truancy among secondary school students: a case study of rivers state, Nigeria, Problems of Education in the $21^{\text {st }}$ Century 45. www.scientiasocialis. $1 \mathrm{t} / \mathrm{pec}$

Khanal, S.P. (2074). Irregular attendance in relation to effect of academic performance of the students in Mid-Western University, Surkhet: Research Management Cell, MU.

Oghuvbu, E. P. (2010). Attendance and academic performance of students in secondary schools: A correlational approach. Studies on Home and Community Science, 4(1). 
128 IRREGULAR ATTENDANCE OF UNIVERSITY STUDENTS ...

Okwakpam, I.N. \& Okwakpam, I.O. (2012). Truancy among secondary level students in Ebonyi South Education Zone. www.wellsfargo. com (Accessed: 12.03.2073 B.S.).

Scheckle, L.A. (2014). An activity theory analysis: Reasons for undergraduate students' absenteeism at a South African University. https://www.researchgate.net/publication/275580352_An_ Activity_Theory_analysis_Reasons_for_undergraduate_students'_ absenteeism_at_a_South_African_university 